\title{
A new Middle Jurassic caddisfly (Trichoptera, Hydrobiosidae) from China
}

\author{
Yan Gao ${ }^{1}$, Yunzhi Yao*,1,2 and Dong Ren ${ }^{1}$ \\ ${ }^{1}$ Key Lab of Insect Evolution and Environmental Changes, Capital Normal University, Beijing 100048, China. E-mail: yaoyz100@gmail.com \\ ${ }^{2}$ State Key Laboratory of Palaeobiology and Stratigraphy (Nanjing Institute of Geology and Palaeontology, CAS), Nanjing 210008, China
}

\begin{abstract}
Received 28 March 2012

Accepted 26 October 2012

Published 20 February 2013

\section{Key Words}

Jiulongshan Formation

Inner Mongolia

Philopotamidae

Material belonging to a new fossil genus and species of caddisfly, Pulchercylindratus punctatus n. gen., n. sp., was collected from the Daohugou locality (Middle Jurassic, Jiulongshan Formation; Inner Mongolia, China). The new species is assigned to the Hydrobiosidae according to subcylindrical shape of the 2nd segment of maxillary palp, the forked $\mathrm{R}_{1}$ (in the forewing, located near apex), and long anal cells (in the forewing). In addition, we propose to transfer the genus Juraphilopotamus Wang, Zhao \& Ren 2009, known from the same locality, to the family Hydrobiosidae, based on the 1 st and 2nd segments of the maxillary palp being cylindrical, shorter than the 3rd segment. A Middle Jurassic origination of family Hydrobiosidae can be established based on the new discovery.
\end{abstract}

\section{Introduction}

The order Trichoptera, so-called "hairy wings", contains three suborders, namely Annulipalpia, Integripalpia, and Spicipalpia, with over 13,000 known extant species. The order is widely distributed around the world, except for the polar regions (Morse 2012), and has an extensive fossil record, with 37 families, 193 genera, and more than 660 species reported to date (Handlirsch 1906-1908, 1939; Meunier 1918; Martynova 1958; Sukastcheva 1968, 1973, 1982, 1990; Erickson 1983; Novokshonov 1993; Botosaneanu 1995; Jarzembowski 1995; Novokshonov et al. 1995; Ansorge 2002; Ivanov \& Sukatsheva 2002; Ivanov \& Melnitsky 2005; Wichard 2007; Wichard et al. 2009, 2011). In particular, four families of Trichoptera (including nine genera and 15 species) have been documented from China (Hong 1983; Lin 1986; Ren et al. 1995; Wang et al. 2009a, 2009b; Davis et al. 2010).

Among caddisflies, the Spicipalpia consists of five extant families, namely Rhyacophilidae, Hydrobiosidae, Glossosomatidae, Hydroptilidae and Ptilocolepidae (Ross 1956; Schmid 1970; Morse 1997; Malicky 2001, 2005; Ward et al. 2004). The family Hydrobiosidae was first erected by Ulmer (1905) as a subfamily of Rhyacophilidae, and granted with family rank by Schmid (1989). This is a large family of approximately 50 genera (Holzenthal et al. 2007). So far, only three genera and three species of the fossil Hydrobiosidae have been reported (Table 1).

Table 1. Fossil species currently ascribed to the family Hydrobiosidae.

\begin{tabular}{llll}
\hline & Species & Age & Locality \\
\hline 1 & Bullivena grandis Novokshonov, Ivanov \& Sukatsheva, 1995 & Late Jurassic & Gobi Altai aymak, Mongolia \\
2 & Palaeohydrobiosis siberambra Botosaneanu \& Wichard, 1983 & Late Cretaceous & East Taymyr, Maimetsha River. Russia \\
3 & Atopsyche perlucida Wichard, 2007 & Tertiary & Dominican amber \\
4 & Juraphilopotamus lubricus Wang, Zhao \& Ren, 2009 & Middle Jurassic & Daohugou, Inner Mongolia, China \\
5 & Pulchercylindratus punctatus n. gen., n. sp. & Middle Jurassic & Daohugou, Inner Mongolia, China \\
\hline
\end{tabular}

* Corresponding author 


\section{Material and methods}

All specimens described here were collected from the Daohugou locality (approximately Bathonian age, or slightly older, ca. $165 \mathrm{Ma}$; Wang \& Ren 2009; Ren et al. 2009, 2010a, 2010b; Rasnitsny \& Zhang 2010; Zhao et al. 2011; Shi et al. 2011; Gao et al. 2012; Gu et al. 2012); Middle Jurassic, Jiulongshan Formation; Shantou Township, Ningcheng County, Inner Mongolia, China), and are housed at the Key Laboratory of Insect Evolution \& Environmental Changes, Capital Normal University (CNU, Beijing, China).

Body length was measured from the head apex to the abdomen apex. Interpretation and terminology used herein follow Holzenthal et al. (2007): C, Costa; Sc, Subcosta; R, Radius; $\mathrm{R}_{1 \mathrm{a}}$ and $\mathrm{R}_{1 \mathrm{~b}}$, anterior and posterior branches of anterior Radius, respectively; Rs, posterior branch of $\mathrm{R}$ (composed of $\mathrm{R}_{2}, \mathrm{R}_{3}, \mathrm{R}_{4}$, and $\mathrm{R}_{5}$ ); $\mathrm{M}$, media; $\mathrm{M}_{1+2}$, anterior branch of Media, composed on $\mathrm{M}_{1}$ and $\mathrm{M}_{2} ; \mathrm{M}_{3+4}$, posterior branch of Media, composed on $\mathrm{M}_{3}$ and $\mathrm{M}_{4} ; \mathrm{Cu}$, Cubitus; $\mathrm{Cu}_{1}$, anterior branch of Cubitus (composed of $\mathrm{Cu}_{1 \mathrm{a}}$ and $\mathrm{Cu}_{1 \mathrm{~b}}$ ); $\mathrm{Cu}_{2}$, posterior branch of Cubitus; 1A, 2A, and 3A, first, second, and third branches of anal vein; the forks giving rise to $R_{2}$ and $R_{3}, R_{4}$ and $R_{5}, M_{1}$ and $\mathrm{M}_{2}, \mathrm{M}_{3}$ and $\mathrm{M}_{4}, \mathrm{CuA}_{1 \mathrm{a}}$ and $\mathrm{CuA}_{1 \mathrm{~b}}$, are referred to as F1, F2, F3, F4, and F5, respectively; the discoidal cell (dc) is the cell formed by the branching of Rs into $\mathrm{R}_{2+3}$ and $\mathrm{R}_{4+5}$ and is closed apically by the sectorial crossvein (s); the medial cell (mc) is formed by the branching of $\mathrm{M}$ into $\mathrm{M}_{1+2}$ and $\mathrm{M}_{3+4}$ and is closed apically by the medial crossvein (m); anal cells delimited by 1A, 2A, and $3 \mathrm{~A}$.

\section{Systematic paleontology}

Order Trichoptera Kirby, 1813

Suborder Spicipalpia Weaver, 1983

Family Hydrobiosidae Ulmer, 1905

\section{Pulchercylindratus n. gen.}

Etymology. Genus name is a combination of the Latin pulcher ('beautiful') and cylindratus ('cylindrical'), gender feminine.

Type species. Pulchercylindratus punctatus n. $\mathrm{sp}$.

Diagnosis. Head round, distinctly narrower than pronotum. Antennae shorter than forewing, filiform, scapus and pedicelli broader than flagellomeres. Maxillary palps five-segmented in both sexes, second segment subcylindrical, all segments of subequal length. Ocelli present. Anterior setal warts and posterolateral setal warts present on the head. Prothorax narrow, a pair of pronotal setal warts visible on pronotum. Wing moderately broad and smoothly rounded distally; $\mathrm{R}_{5}$ reaching wing apex; $\mathrm{R}_{1}$ forked distally; discoidal and medial cells closed in forewings, but discoidal cell open in hind-wings; Rs stem nearly twice as long as discoidal cell; Rs and $\mathrm{M}$ four-branched, respectively; $F_{1}-F_{5}$ present in forewings; anal cells long. Tibial spurs: 2, 4, 4 .

Remarks. The type species of the genus can be assigned to the family Hydrobiosidae by the following combination of features: antenna with stout scapus, shorter than head; maxillary palps 5-segmented, with 2nd segment as short as 1st segment or longer, both segments shorter than following ones; 4th and 5th segments as long as 3rd one, or longer, distally rounded (Fig. 2E); in forewings $\mathrm{R}_{1}$ forked at apex (reduced or simple in few Hydrobiosidae genera only); long anal cells. The discoidal being open or closed is not conclusive on the familial assignment of the genus, because both states can be found in the Hydrobiosidae.
Pulchercylindratus gen. nov. is characterized by the second segment of maxillary palps being subcylindrical (as opposed to globose), discoidal and medial cells closed, forewing with all $\mathrm{F}_{1}-\mathrm{F}_{5}$ present, and long anal cells. The new genus appears similar to the extant genus Rhyacophila Pictet, 1834 (in the family Rhyacophilidae; Fig. 4C), but it can be distinguished easily from the latter by its maxillary palps with the 2nd segments being globose (in contrast to subcylindrical), and the anal cells short (in contrast to long).

The new taxon is to be compared with known fossil Hydrobiosidae. Compared with the genus Bullivena Novokshonov et al., 1995, the new genus has no particular thickening of $\mathrm{R}$, lacks the crossvein connecting $\mathrm{R}_{5}$ with $\mathrm{M}_{1+2}$, and has a closed discoidal cell (in contrast to an open discoidal cell). Compared with the genus Palaeohydrobiosis Botosaneanu et al., 1983, the new genus has a closed discoidal cell, and $F_{1}$ longer than $F_{2}$ (as opposed to $F_{1}$ shorter than $F_{2}$ ). Compared with the genus Atopsyche Wichard, 2007, the new genus has maxillary palps with the terminal segment being not particularly elongate (as opposed to very elongate), a median cell open, $M$ fork located at the first third of

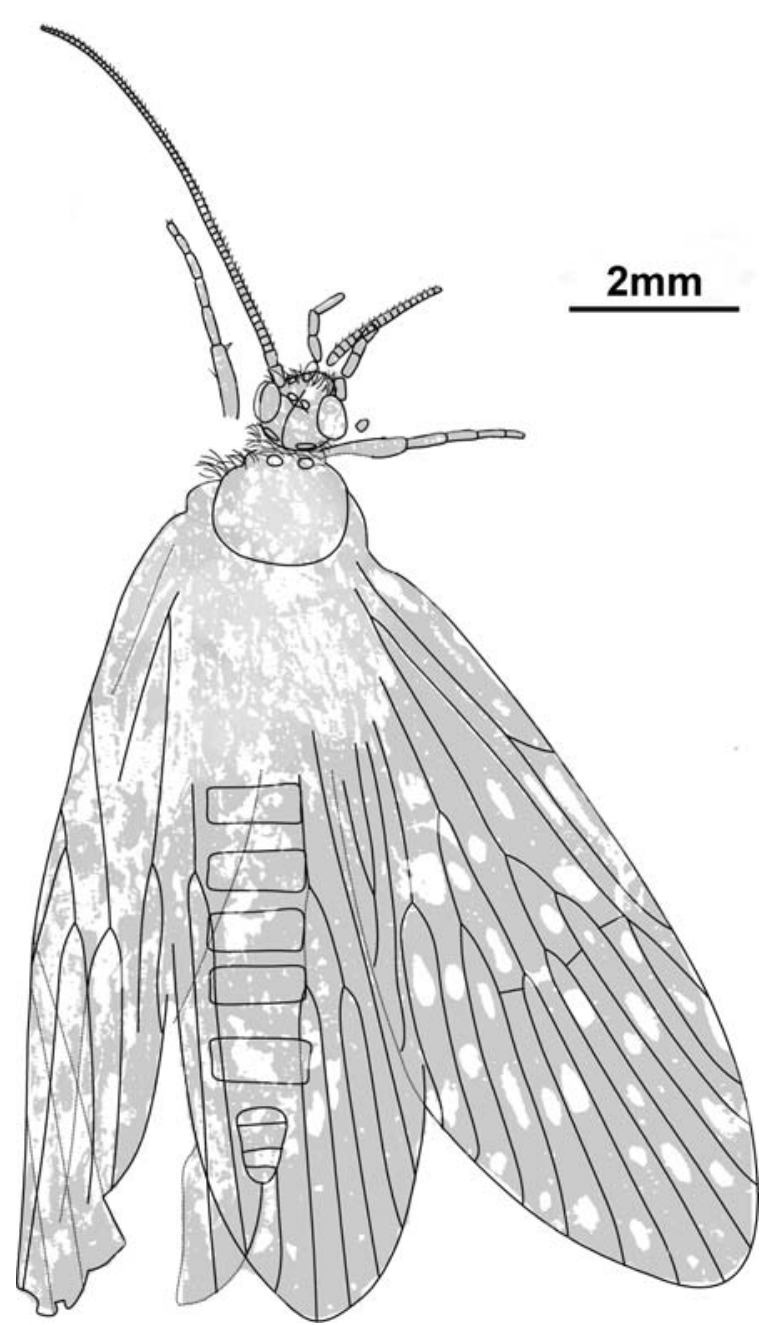

Figure 1. Pulchercylindratus punctatus n. gen., n. sp. Line drawing of holotype, CNU-Tri-NN2011003. 

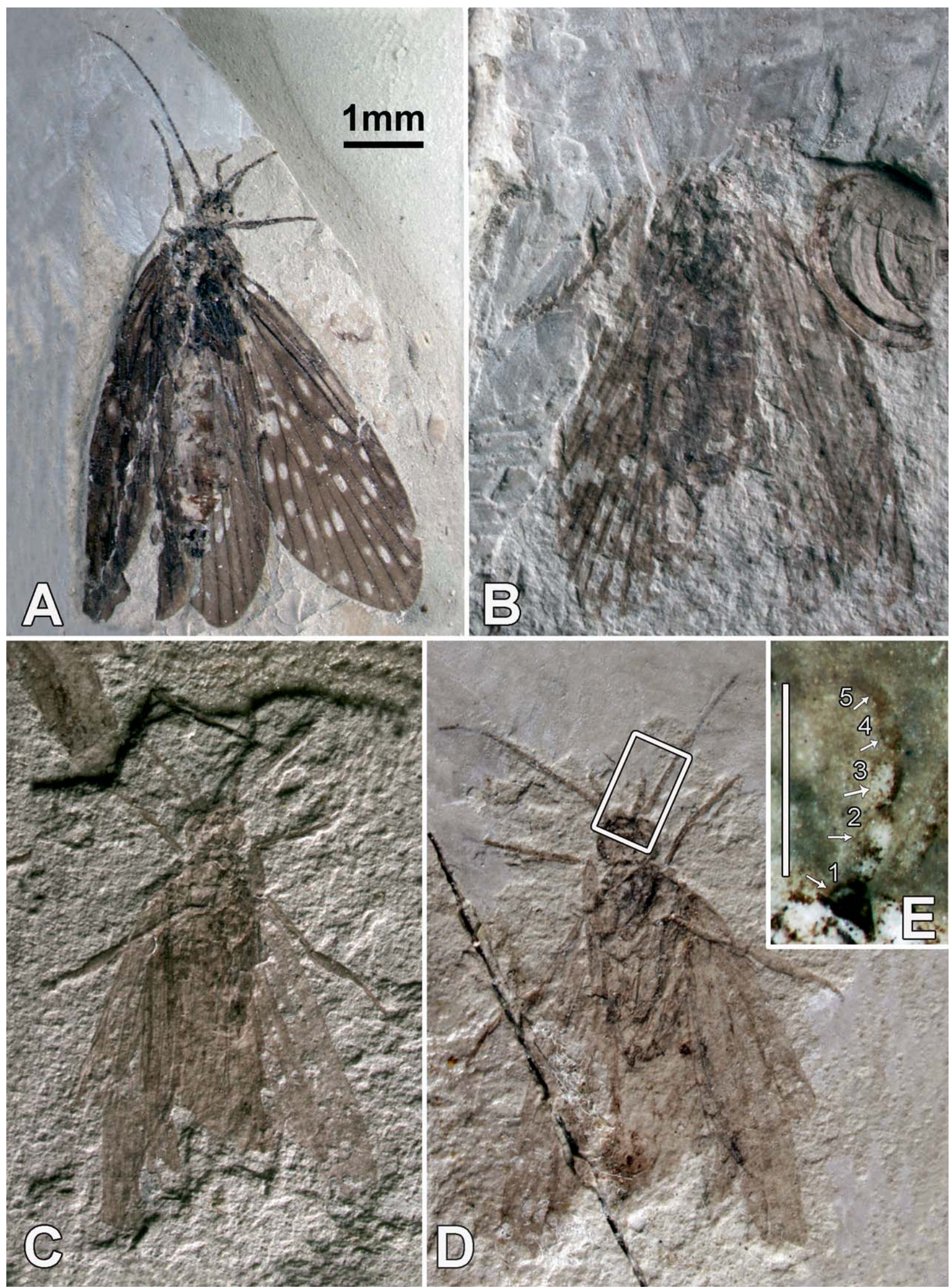

Figure 2. Photographs of Pulchercylindratus punctatus n. gen., n. sp.; A. CNU-Tri-NN2011003; B. CNU-Tri-NN2011005; C-D. CNU-Tri-NN2011004PC; E. Maxillary palps. 

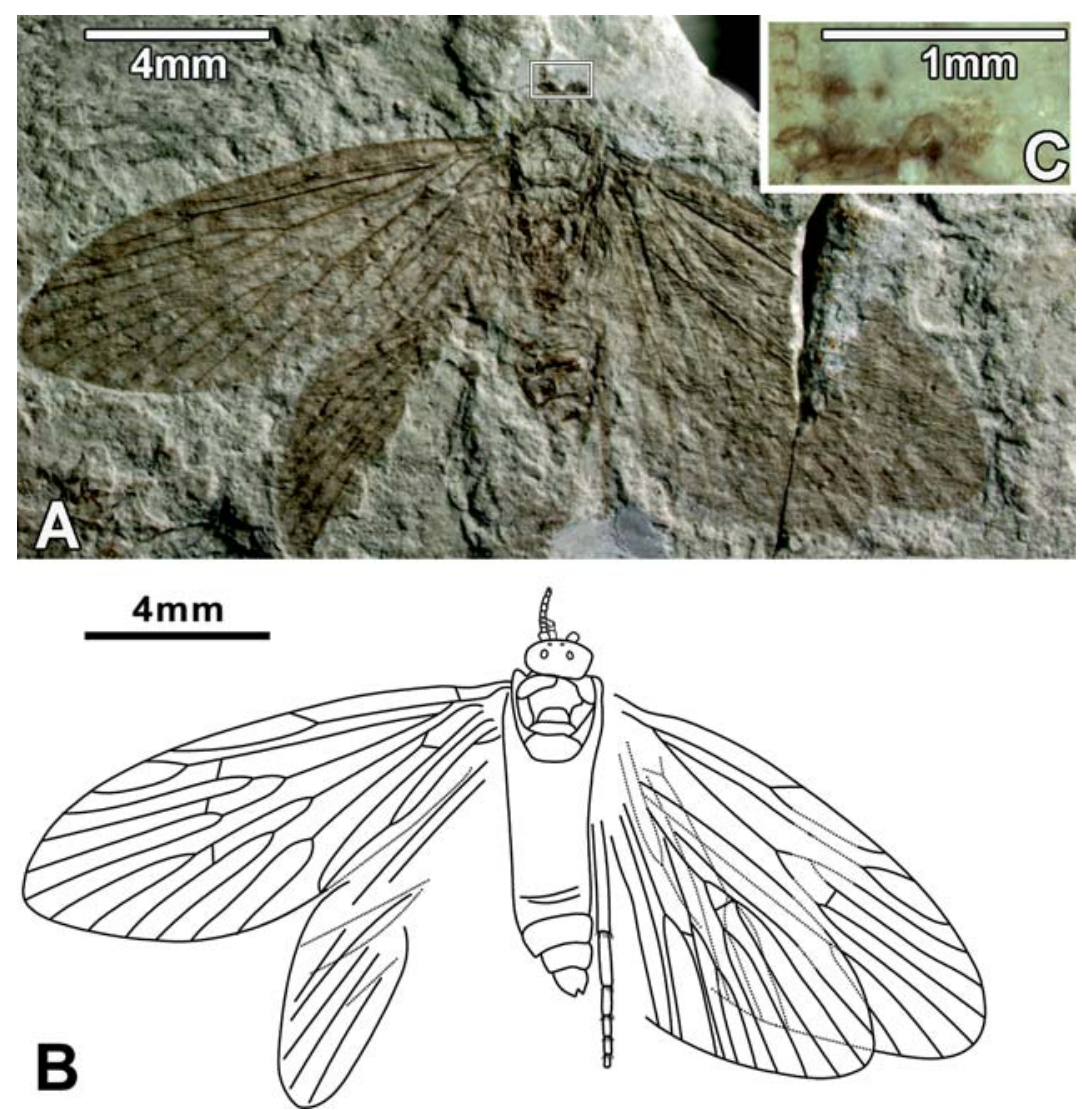

Figure 3. Juraphilopotamus lubricus Wang, Zhao \& Ren 2009. A-B. specimen CNU-Tri-NN-2007001 (holotype), photograph (A) and line drawing (B); C. Maxillary palps (under ethyl alcohol). forewing length (as opposed to located at the forewing mid-length), and $F_{1}$ longer than $F_{2}$ (as opposed to $F_{1}$ shorter than $\mathrm{F}_{2}$ ).

\section{Pulchercylindratus punctatus n. sp.}

Figures 1-3, 4A

Etymology. Name derived from the Latin punctatus ('spotted').

Locality and horizon. Daohugou Village, Shantou Township, Ningcheng County, Inner Mongolia, China (N 41 ${ }^{\circ} 18.979^{\prime}$, E $119^{\circ} 14.318^{\prime}$ ); Jiulongshan Formation, Middle Jurassic.

Material. Holotype, ô, CNU-Tri-NN2011003; paratypes, CNU-TriNN2011004PC (dorsoventrally compressed, part and counterpart), CNU-Tri-NN2011005 (laterally compressed).

Diagnosis. Two pairs of setal warts in dorsal view, anterior setal warts small and symmetrical; posterolateral setal warts prolate and obscure. Antennae with stout scapus and slender flagellomeres, many spines distributed on inner side of antennae.
Wings (Fig. 4A): forewings, Sc straight, with an oblique crossvein reaching anterior wing margin before half of wing length; Rs forked basal to wing mid-length; stem of Rs nearly twice as long as discoidal cell; $F_{1}$ parallel to $F_{2} ; M$ fork located opposite the first third of forewing length; medial cell longer than discoidal cell; $\mathrm{Cu}_{1}$ and $\mathrm{Rs}$ forked at the same level; $\mathrm{Cu}_{2}$ and anal vein $\mathrm{A}_{1+2+3}$ distinct.

Measurements (in mm). Holotype, ô, CNU-TriNN2011003 (Figs 1, 2A): Body length 10.47, maximal width of body 8.24 ; head length 0.88 , width 1.06 ; length antennal segments (scapus, pedicelli, flagellomeres): $0.29,0.18,3.88$; Maxillary palp I-V: 0.12 , $0.29,0.35,0.35,0.41$; compound eye length $0.53,0.35$; thorax length 1.35 , width 1.53 ; forewing length 9.06 , width 3.47 , Sc 5.47, $\mathrm{R}_{1}$ 6.17, Rs 3.17, $\mathrm{R}_{2+3} 0.73$, $\mathrm{R}_{4+5} 1.17, \mathrm{M} 2.83, \mathrm{M}_{1+2} 2.13, \mathrm{M}_{3+4} 1.13, \mathrm{Cu}_{1} 3.73$, $\mathrm{Cu}_{2} 5.00,1 \mathrm{~A} 1.77,2 \mathrm{~A} 1.40,1 \mathrm{~A}+2 \mathrm{~A} 0.87$; dc 1.43 mc $2.23, \mathrm{~F}_{1-5} 3.83,4.33,3.77,3.53,2.80$, hind-wing length 4.71 , width 2.65 ; length fore leg: tibia 1.00 , tar-
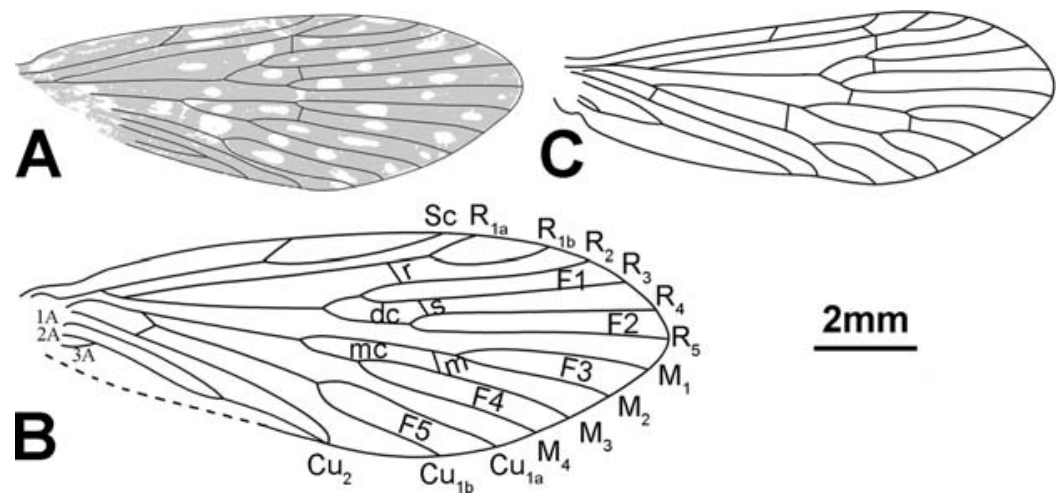

$2 \mathrm{~mm}$
Figure 4. Forewing line drawings A. Pulchercylindratus punctatus n. gen., n. sp.; B. Juraphilopotamus lubricus Wang, Zhao \& Ren 2009. $\mathbf{F}_{1-5}$ - apical forks 1-5; dc discoidal cell; mc - median cell; C. Rhyacophila chandleri Denning, 1956 (based on Giersch 2002). 
someres I-V: $0.53,0.41,0.35,0.29,0.18$; abdomen length 4.24, width 1.18; ovipositor length 0.88; Paratype, CNU-Tri-NN2011004PC (dorsoventrally compressed, part and counterpart (Figs 2C, D)) body length 6.04 , maximal width of body 2.55 ; head length 0.94 , width 1.11; length antennae 3.74; Maxillary palp I-V: $0.12,0.29,0.35,0.35,0.41$; thorax length 1.19 , width 1.53; forewing length 7.40 , width 1.96 ; length fore leg: tibia 1.00 , tarsomeres I-V: $0.53,0.41,0.35,0.29,0.18$; abdomen length 4.24, width 1.18; Paratype, CNU-TriNN2011005 body length 5.78, maximal width of body 1.96 ; length pronotum 0.77 , width 0.54 ; length fore leg: tibia 2.55, tarsomeres 1.45; forewing length 7.82 , width 2.89; abdomen length 5.70, width 0.55 .

\section{Discussion}

Wang, Zhao \& Ren (2009b) erected the species Juraphilopotamus lubricus based on a single specimen from the Daohugou locality, and placed it to the family Philopotamidae, based on wing venation characters. The argument proposed by Wang et al. (2009b; Fig. 3) for this assignment, based on family diagnosis in Carpenter (1992, p. 363), was 'discoidal cell and medial cell closed'. It is worth mentioning that traditionally the wing venation characters are widely used for the taxonomy of fossil Trichoptera. However these characters can prove insufficient for family diagnoses, and should ideally be complemented by body characters (Ivanov \& Melnitsky 2006; also, the polarity of wing characters was never tested).

Regarding the current case, the family Philopotamidae is characterized by 5-segmented maxillary palps in both sexes, with the 1 st segment being the shortest, the 2nd one being provided with a mesodistal brush of setae, and the 5th segment long, annulate and flexible, usually at least twice as long as preceding segment (Neboiss 1991; Wiggins 2008). Reinvestigation of the material described by Wang et al. (2009b) reveals that only the basal three segments of one maxillary palp are preserved, with the 1 st and 2 nd segments being cylindrical and shorter than the 3rd segment (Fig. 3C). This suggests that the species does not belong to the Philopotamidae, but more likely to the family Hydrobiosidae (in which the 1st and 2nd segments cylindrical and shorter than the 3rd segment). Therefore we propose to transfer J. lubricus from the family Philopotamidae to the Hydrobiosidae.

As previously documented, the first appearance of the Hydrobiosidae is Late Jurassic, with Bullivena grandis Novokshonov et al., 1995. Ivanov \& Sukatsheva (2002) also postulated a Late Jurassic origination of the family. Thanks to discovery of Pulchercylindratus punctatus n. gen., n. sp., a Middle Jurassic origination can be established.

\section{Acknowledgements}

We sincerely thank the reviewers of this paper (one anonymous and Wilfried Wichard, Köln) for their improvement of our manuscript. We are also grateful to Olivier Béthoux for useful discussion, and Yingying Cui for help with photographs. This research was funded by grants from National Basic Research Program of China (973 Program) (No. 2012CB821900); Fok Ying-Tong Education Foundation for Young Teachers in the Higher Education Institutions of China (No. 131021); the National Natural Science Foundation of China (No. 31071964, 41272006, 31230065); the General Program of Science and Technology Development Project of Beijing Municipal Education Commission of China (No. KM201210028016); the PHR Project of Beijing Municipal Commission of Education (No. 201107120) and the State Key Laboratory of Palaeobiology and Stratigraphy (Nanjing Institute of Geology and Palaeontology, CAS) (No.123114).

\section{References}

Ansorge, J. 2002. Revision of the "Trichoptera" described by Geinitz and Handlirsch from the Lower Toarcian of Dobbertin (Germany) based new material. - Proceedings of the 10th International Symposium on Trichoptera. - Nova Supplementa Entomologica, Keltern: $55-74$.

Botosaneanu, L. \& Wichard, W. 1983. Upper-Cretaceous Siberian and Canadian Amber Caddisflies (Insecta: Trichoptera). - Bijdragen tot de Dierkunde 53: 187-217.

Botosaneanu, L. 1995. Caddisflies (Trichoptera) from Turonian Upper-Cretaceous amber of New Jersey. - American Museum Novitates 10024 (3140): 1-7.

Carpenter, F. M. 1992. Treatise on Invertebrate Palaeontology. Part R. Arthropoda 4 (3). Superclass Hexapoda. Geological Society American and University Kansas, Baulder, Colorado and Lawrence: pp. $1-617$.

Davis, S. R., Engel, M. S. \& Ren Dong 2010. A pupal caddisfly from the Early Cretaceous of China (Trichoptera). - Cretaceous Research 31 (4): 396-399.

Erickson, J. M. 1983. Trichopterodomus leonardi, a new genus and species of psychomyiid caddisfly (Insecta: Trichoptera) represented by retreats from the Paleocene of North Dakota. - Journal of Paleontology 57: 560-567.

Gao Taiping, Shih, C. K., Xu Xing, Wang Shuo \& Ren Dong 2012. Mid-Mesozoic Flea-like Ectoparasites of Feathered or Haired Vertebrates. - Current Biology 22 (8): 732-735

Giersch, J. J. 2002. Revision and phylogenetic analysis of the verrula and alberta species groups of Rhyacophila Pictet 1834 with description of a new species (Trichoptera: Rhyacophilidae). Master dissertation, Montana State University, Bozeman, Montana.

Gu Junjie, Montealegre-Z., F., Robert, D., Engel, M. S., Qiao Gexia \& Ren Dong 2012. Wing stridulation in a Jurassic katydid (Insecta, Orthoptera) produced low-pitched musical calls to attract female. - Proceedings of the National Academy of Sciences USA (PNAS) 109 (10): 3868-3873.

Handlirsch, A. 1906-1908. Die fossilen Insekten und die Phylogenie der rezenten Formen. Ein Handbuch für Paläontologen und Zoologen. Engelmann, Leipzig. 1-1430. [pp. 1-640 were published 1906, 641-1430 were published 1908].

Handlirsch, A. 1939. Neue Untersuchungen iiber die fossilen lnsekten mit Erganzungen und Nachtragen sowie Ausblicken auf phylogenetische, palaeogeographische und allgemein biologische Probleme. II Teil. - Naturhistorisches Museum Wien 49: 1-240.

Holzenthal, R. W., Blahnik R. J., Prather A. L. \& Kjer, K. M. 2007. Order Trichoptera Kirby, 1983 (Insecta), caddisflies. - Zootaxa 1668: 639-698.

Hong Youchong 1983. Middle Jurassic Fossil Insects in North China. Geological Publishing House, Beijing. 
Ivanov, V. D. \& Sukatsheva, I. D. 2002. Order Trichoptera Kirby, 1813, caddisflies. - In Rasnitsyn, A. P. \& Quicke, D. L. J. (eds). History of Insects. Kluwer Academic Publishers, Dordrecht, Boston, London: pp. 199-219.

Ivanov, V. D. \& Melnitsky, S. I. 2005. New caddisfly species of the genus Wormaldia (Trichoptera: Philopotamidae) from Baltic amber. - Paleonotological Jounal 39 (3): 284-288.

Ivanov, V. D. \& Melnitsky, S. I. 2006. The Morphology of Dajella tenera (Trichoptera, Glossosomatidae): Taxonomic Status and Evidence for the Pheromone Communication in the Mesozoic. - Entomological Review 85 (2): 365-374.

Jarzembowski, E. A. 1995. Fossil caddisflies (Insecta: Trichoptera) from the Early Cretaceous of southern England. - Cretaceous Research 16: 695-703.

Lin Qibin 1986. Early Mesozoic fossil insect from the South China. Palaeontologica Sinica Science Press, Beijing.

Malicky, H. 2001. Notes on the taxonomy of Rhadicoleptus, Ptilocolepus and Pseudoneureclipsis. - Braueria 28: 19-20.

Malicky, H. 2005. Ein kommentiertes Verzeichnis der Köcherfliegen (Trichoptera) Europas und des Mediterrangebiets. - Linzer Biologische Beiträge 37: 533-596.

Martynova, O. M. 1958. New insects from Permian and Mesozoic deposits of the USSR. - Materialy po Osnovam Paleontologii 2: 69-94 [in Russian].

Morse, J. C. 1997. Phylogeny of Trichoptera. - Annual Review of Entomology 42: 427-450.

Morse, J. C. (ed.) 2012. Trichoptera World Checklist. http://entweb.clemson.edu/database/trichopt/index.htm [accessed 18 April 2012.]

Meunier, F. 1918. Eine neue Phryganiden-Art aus den Gipspplatten von Aix (Provence). - Entomologische Mitteilungen 7: 198-199.

Mey, W. 1988. The caddisflies of the Saxonian Amber (III) (Trichoptera). - Deutsche Entomologische Zeitschrift 35: 299-309.

Neboiss, A. 1991. Trichoptera (caddis-flies, caddisfly). In The insects of Australia. Carlton: Melbourne University Press: pp. 787-817.

Novokshonov, V. G. 1993. Caddis Flies (Insecta, Trichoptera, Microptysmatidae). - Paleontological Journal 27 (1A): 90-102.

Novokshonov, V. G., Ivanov, V. D. \& Sukatsheva, I. D. 1995. New Jurassic caddis flies (Insecta, Phryaneida $=$ Trichoptera) from Siberia and Mongolia - Paleontological Journal 29 (4): 157-163.

Rasnitsny, A. P. \& Zhang Haichun 2010. Early evolution of Apocrita (Insecta, Hymenopt) as indicated by new findings in the Middle Jurssic of Daohugou, Northeast China. - Acta Geologica Sinica (English edition) 84 (4): 843-873.

Ren Dong, Lu Liwu, Guo Ziguang \& Ji Shuan 1995. Faunae and stratigraphy of Jurassic - Cretaceous in Beijing and the Adjacent Areas. Seismic Publishing House, Beijing.

Ren Dong, Labandeira, C. C., Santiago-Blay, J. A., Rasnitsyn, A., Shih, C. K., Bashkuev, A., Logan, M. A., Hotton, C. L. \& Dilcher, D. 2009. A probable pollination mode before angiosperms: Eurasian, long-proboscid scorpionflies. - Science 326 (5954): 840-847.

Ren Dong, Labandeira, C. C. \& Shih, C. K. 2010a. New Mesozoic Mesopsychidae (Mecoptera) from Northeastern China. - Acta Geologica Sinica (English edition) 84 (4): 720-731.

Ren Dong, Shih, C. K., Gao Taiping, Yao Yunzhi \& Zhao Yunyun 2010b. Silent Stories. Insect Fossil Treasures from Dinosaur Era of the Northeastern China. Science Press, Beijing.

Ross, H. H. 1956. Evolution and Classification of the Mountain Caddisflies. University of Illinois Press, Urbana.

Schmid, F. 1970. Le genre Rhyacophila et la famille des Rhyacophilidae (Trichoptera). Memoires de la Société Entomologique du Canada.
Schmid, F. 1989. Les hydrobiosides (Trichoptera, Annulipalpia). Bulletin de 1'Institute Royal des Sciences Naturelles de Belgique, Entomologie 59, Supplement: 1-154.

Shi Chaofan, Yang Qiang \& Ren Dong 2011. Two new fossil lacewing species from the Middle Jurassic of Inner Mongolia, China (Neuroptera: Grammolingiidae). - Acta Geologica Sinica (English Edition) 85 (2): 842-849.

Sukatcheva, I. D. 1968. Mesozoic caddisflies (Trichoptera) from the Zabaikalia. - Palaentological Journal 2: 59-75 [in Russian].

Sukatcheva, I. D. 1973. New caddisflies (Trichoptera) from Mesozoic Middle Asia. - Paleontologaical Journal 3: 100-107 [in Russian].

Sukatcheva, I. D. 1982. History development of the Trichoptera. Transactons of the Paleontological Institute of the Academy of Science of the USSR 197: 1-111 [in Russian].

Sukastcheva, I. D. 1990. Description of fossil insect, Caddisflies, Phryganeida. Late Mesozoic insects of Eastern Transbaikalia. Transactons of the Paleontological Institute of the Academy of Science of the USSR 239: 94-122 [in Russian].

Sukatsheva, I. D. \& Jarzembowski, E. A. 2001. Fossil caddisflies (Insecta: Trichoptera) from the Early Cretaceous of South Englang II. Cretaceous Research 22: 685-694.

Ulmer, G. 1905. Neue und wenig bekanme aussereuropaische Trichopteren, hauptsachlich aus dem Wiener Museum. - Annalen des Narurhistorischen Museums in Wien 20: 59-98.

Wang Meixia, Zhao Yunyun \& Ren Dong 2009a. New fossil Vitimotauliidae (Insecta: Trichoptera) from the Jehol Biota of Liaoning, China. - Cretaceous Research 30 (3): 592-598.

Wang Meixia, Zhao Yunyun \& Ren Dong 2009b. New fossil caddisfly from Middle Jurassic of Daohugou, Inner Mongolia, China (Trichoptera: Philopotamidae). - Progess in Natural Science 19 (10): 1427-1431

Wang Ying \& Ren Dong 2009. New fossil Palaeontinids from the Middle Jurassic of Daohugou, Inner Mongolia, China (Insecta, Hemiptera). - Acta Geologica Sinica (English edition) 83 (1): 33-38.

Ward, J. B., Leschen, R. A. B., Smith, B. J. \& Dean, J. C. 2004. Phylogeny of the caddisfly (Trichoptera) family Hydrobiosidae using larval and adult morphology, with the description of a new genus and species from Fiordland. - Records of the Canterbury Museum, New Zealand 18: 23-43.

Weaver, J. S. 1983. The evolution and classification of Trichoptera, with a revision of the Lepidostomatidae and a North American synopsis of this family. Ph.D. dissertation, Clemson Univ. Clemson, South Carolina.

Wichard, W. 2007. Overview and descriptions of caddisflies (Insecta, Trichoptera) in Dominican amber. - Stuttgarter Beiträge zur Naturkunde, Serie B (Geologie und Paläontologie) 336: 1-51.

Wichard, W., Gröhn, C. \& Seredszus, F. 2009. Aquatic Insects in Baltic Amber. Verlag Kessel, Remagen: pp. 1-335.

Wichard, W., Ross, E. \& Ross, A. 2011. Palerasnitsynus gen. n. (Trichoptera, Psychomyiidae) from Burmese amber. - Zookeys 130: 323-330.

Wiggins, G. B. \& Currie, D. C. 2008. Chapter 17. Trichoptera families. In Merritt, R. W., Cummins, K. W. \& Berg, M. B. (eds). An introduction to the aquatic insects of North America. Kendall/ Hunt Publishing C., Dubuque, Iowa: pp. 439-480.

Zhao Jingxia, Shih, C. K., Ren Dong \& Zhao Yunyun 2011. New Primitive Fossil Earwig from Daohugou, Inner Mongolia, China (Insecta: Dermaptera: Archidermaptera). - Acta Geologica Sinica (English edition) 85 (1): 75-80 